Sari Pediatri, Vol. 7, No. 3, Desember 2005: 143 - 148

\title{
Peran Eritropoetin pada Anemia Bayi Prematur
}

\author{
Lily Rahmawati, Bidasari Lubis
}

Anemia sering terjadi pada bayi prematur, ditandai oleh penurunan nilai hematokrit, retikulosit dan kadar eritropoetin endogen rendah. Di Amerika Serikat, 60-80\% bayi berat lahir sangat rendah (BBLSR) mengalami anemia dan membutuhkan transfusi sel darah merah berulang sehingga mempunyai risiko terjadi komplikasi penularan penyakit. Salah satu upaya menurunkan kebutuhan transfusi tersebut dengan pemberian eritropoetin eksogen yaitu recombinant human eritropoietin ( $r-H U E P O)$ yang berfungsi merangsang proliferasi, diferensiasi dan maturasi sel darah merah dalam sumsum tulang. Walaupun pada bayi prematur dijumpai kadar eritropoetin yang sangat rendah, namun progenitor eritroid tetap sensitif terhadap eritropoetin eksogen. Pemberian $r-H U$ EPO dapat meningkatkan eritropoesis sehingga bermanfaat mengurangi kebutuhan transfusi pada anemia bayi prematur. Pemberian dalam dosis cukup pada usia dini, suplementasi preparat besi dan protein mempunyai efektifitas yang baik. Berbagai penelitian terhadap penggunaan $r-H U E P O$ pada anemia bayi prematur telah dilakukan tetapi belum ada kesepakatan mengenai protokol pemberian, termasuk waktu, dosis, cara, dan durasi pemberian.

Kata kunci: anemia, bayi prematur, eritropoetin.

$2^{\mathrm{a}}$ nemia adalah berkurangnya sel darah merah atau konsentrasi hemoglobin akibat gangguan keseimbangan antara kehilangan sel darah merah dan gangguan produksi. Anemia dapat terjadi pada bayi prematur. Hal ini akibat dari menurunnya produksi sel darah merah, meningkatnya penghancuran sel darah merah dan kehilangan darah iatrogenik. Anemia pada bayi prematur terjadi disebabkan oleh berkurangnya sel darah merah pada bayi kurang bulan, ditandai oleh penurunan nilai hematokrit, retikulosit dan konsentrasi eritropoetin endogen rendah., ${ }^{1,2}$

\footnotetext{
Alamat korespondensi:

Dr. Lily Rahmawati

Bagian Ilmu Kesehatan Anak Fakultas Kedokteran Universitas Sumatera Utara/ RSUP H.Adam Malik Jl. Bunga Lau no.17 Medan.

Tel (061) 8361721 - 8365663 Fax. (061) 8361721 E-mail : bikafkusu@telkom.net; kotak Pos 697 Medan - 20136
}

Insidens kelahiran prematur dengan berat badan lahir sangat rendah $(\mathrm{BBL}<1500$ gram) di Amerika Serikat $1,4 \%$ dari seluruh kelahiran hidup. Diperkirakan $60-80 \%$ bayi berat lahir sangat rendah (BBLSR) tersebut mengalami anemia dan membutuhkan transfusi sel darah merah. Rerata jumlah transfusi yang diperlukan 9-13 kali per bulan dan rerata jumlah donor 7-10 orang untuk tiap bayi. ${ }^{3}$ Pemberian transfusi darah berulang mempunyai risiko terjadi komplikasi penularan penyakit (transfusion transmitted disease)., ${ }^{2,4}$

Berbagai upaya dilakukan untuk menurunkan kebutuhan transfusi sel darah merah yang berulang pada bayi prematur. Salah satu cara adalah pemberian eritropoetin eksogen (recombinant human erthropoietin=r-HU EPO) yang telah dimulai sejak tahun 1988. Beberapa tahun terakhir ini makin banyak peneliti yang melaporkan pengaruh dan manfaat pemberian $r$-HU EPO pada anemia bayi prematur. ${ }^{1-6,8}$

Recombinant human erythropoietin merupakan hasil rekayasa genetik (recombinant DNA technology) yang 
identik dengan eritropoetin endogen. Terdiri dari struktur glikoprotein 165 asam amino dengan berat molekul 30,4 kD yang diproduksi melalui kultur sel jaringan hewan mamalia disebut chines hamster ovary cell (CHO cell). Preparat $r-H U$ EPO berpengaruh merangsang proliferasi, diferensiasi dan maturasi sel darah merah di sumsum tulang, meningkatkan jumlah sel darah merah dan selanjutnya meningkatkan cadangan oksigen serta memperbaiki kemampuan penyebaran oksigen. ${ }^{7,9,10}$

Tujuan dari tulisan ini adalah untuk menjelaskan tentang peran eritropoetin untuk meningkatkan kadar hemoglobin pada anemia bayi prematur.

\section{Patofisiologi Anemia pada Bayi Prematur}

Perkembangan hematopoesis dalam rahim terbagi 3 periode yaitu mesoblastik, hepatik dan mieloid. Periode mesoblastik dimulai pada masa gestasi 2 minggu saat itu sel-sel darah merah dibentuk di indung telur (yolk sac). Pada periode hepatik sel-sel normoblas dibentuk di hati dan terjadi pada masa gestasi 6-24 minggu. Pada masa gestasi 6-7 bulan dan selanjutnya adalah periode mieloid, yaitu sumsum tulang merupakan tempat eritropoesis dan satu-satunya sumber sel darah baru selama masa anak. ${ }^{11,12}$

Mekanisme regulasi eritropoesis pada janin dan bayi prematur belum jelas. Dalam rahim, eritropoesis dikontrol oleh erythroid growth factors yang hanya dihasilkan oleh janin, diproduksikan oleh sel-sel asesoris seperti sel makrofag, limfosit, stroma dan berperan merangsang pertumbuhan, diferensiasi dan maturasi sel-sel darah merah pada periode hepatik dan mieloid. Dari semua faktor-faktor yang merangsang eritropoesis, eritropoetin merupakan regulator yang memegang peran paling penting. ${ }^{1,12}$

Eritropoetin adalah suatu sitokin spesifik, sialoglikoprotein yang tersusun dari 165 asam amino dengan berat molekul 30-39 kD, terikat pada reseptor spesifik di permukaan prekursor eritroid dan berfungsi merangsang proliferasi, diferensiasi dan maturasi sel darah merah., ${ }^{912-14}$ Regulasi eritropoetin dipengaruhi oleh mekanisme oksigenisasi. Keadaan hipoksia atau anemia memicu eritropoesis dengan cara merangsang transkripsi m-RNA dan menghasilkan eritropoetin. ${ }^{12}$ Kadar normal eritropoetin plasma berkisar 0,01-0,03 unit/ml dan meningkat 100-1000 kali pada keadaan hipoksia atau anemia. ${ }^{10}$

Eritropoetin dihasilkan oleh hati janin pada trimester I dan II, sedangkan pada trimester III dan satu minggu pertama setelah eritropoetin dihasilkan oleh ginjal. Proses perubahan ini belum jelas diketahui, tetapi mungkin disebabkan perubahan tekanan oksigen arteri pada waktu lahir. ${ }^{12}$ (Gambar 1)

Pada bayi prematur dijumpai kadar eritropoetin yang sangat rendah. Namun progenitor eritroidnya tetap sensitif terhadap eritropoetin eksogen. Hal ini menjelaskan bahwa menurunnya eritropoesis bayi prematur terjadi akibat produksi eritropoetin yang tidak adekuat, walaupun beberapa hematopoietic growth factors lain juga ikut berperan. ${ }^{1,11,15-17}$

Semua bayi baru lahir akan mengalami penurunan hemoglobin pada minggu pertama kehidupan; namun pada bayi prematur penurunan tersebut sering terjadi

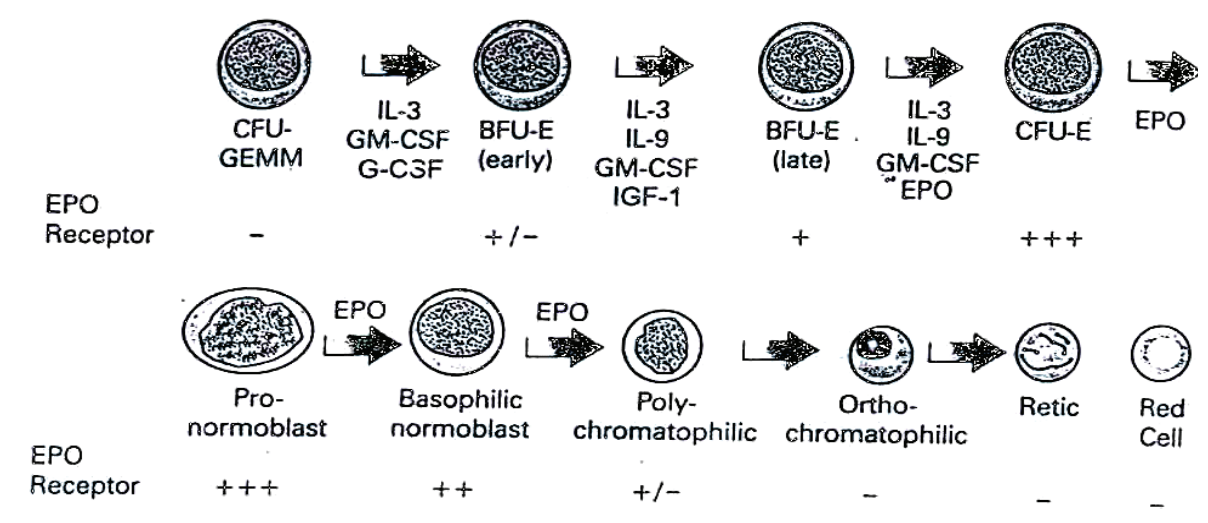

Gambar 1. Peran eritropoetin pada eritropoesis. ${ }^{13}$ 
sejak lahir, lebih cepat dan berlebihan. Kecepatan dan besarnya penurunan ini sesuai dengan tingkat imaturitas bayi. Pada bayi dengan berat lahir 1,2 - 2,3 $\mathrm{kg}$, hemoglobin turun 9,6 $\pm 1,4 \mathrm{~g} / \mathrm{dl}$ sedangkan pada berat lahir di bawah $1,2 \mathrm{~kg}$ terjadi penurunan sampai $7,8 \pm 1,4 \mathrm{~g} / \mathrm{dl} .{ }^{1}$ Nilai normal hemoglobin bayi cukup bulan adalah 16,8 g/dl $(14-20 \mathrm{~g} / \mathrm{dl})$ dan bayi berat lahir sangat rendah (BBLSR) $1-2 \mathrm{~g} / \mathrm{dl}$ di bawahnya. ${ }^{2}$ Penurunan hemoglobin sampai $7-9 \mathrm{~g} / \mathrm{dl}$ terjadi pada minggu ke 3 - 6 dan akan lebih rendah lagi pada bayi yang sangat kecil. Nilai hematokrit berkisar $20-30 \%$ dan jumlah retikulosit rendah sampai 100-150 x 10\% 1. ${ }^{1,15,16}$ Beberapa bayi dapat bertoleransi terhadap keadaan ini namun bayi lain dapat menunjukkan tanda klinis berupa pucat, takikardi, bradikardi, takipnu, apnu, aktifitas menurun dan berat badan tidak naik. ${ }^{1,2,15}$

Anemia pada bayi prematur pada dasarnya disebabkan oleh beberapa faktor. Masa eritrosit bayi prematur pada waktu lahir lebih rendah dan lama hidup eritrosit lebih pendek (35-50 hari). Kadar eritropoetin serum turun dengan cepat sesudah lahir karena terpapar dengan lingkungan ekstrauterin yang relatif lebih kaya oksigen. Selanjutnya eritropoetin yang diproduksi oleh hati janin mempunyai respon yang sangat rendah terhadap mekanisme oksigenisasi seperti keadaan anemia dan hipoksia. Ekspansi cairan intravaskular yang berhubungan dengan cepatnya pertumbuhan juga menyebabkan hemodilusi dan bersama-sama dengan faktor lain menyebabkan konsentrasi hemoglobin rendah pada beberapa bulan pertama usia bayi prematur. Kehilangan darah juga terjadi akibat pengambilan sampel darah untuk diagnostik dan pemantauan, hal ini kira-kira 90\% merupakan penyebab kebutuhan transfusi darah merah. Kemampuan jaringan mengikat oksigen yang rendah, kadar hemopoietic growth factor lainnya yang rendah, dan defisiensi nutrisi juga merupakan faktor penyebab anemia pada bayi prematur. ${ }^{2,3,15,16}$

\section{Penggunaan Recombinant Human Erythropoietin (r-HU EPO)}

Sejumlah penelitian telah dilakukan sejak tahun 1980an terhadap penggunaan $r-H U E P O$ pada bayi prematur yang mengalami anemia sebagai alternatif usaha untuk mengurangi penggunaan produk darah dan untuk menghindari komplikasi transfusi. ${ }^{9,16}$
Walaupun bayi prematur mempunyai kadar eritropoetin yang rendah, namun telah terbukti bahwa progenitor eritroidnya tetap sensitif terhadap eritropoetin eksogen. ${ }^{13,12,16-18}$ Shanon dkk, pada percobaan in vitro memperlihatkan hal tersebut dan keadaan ini memberi tempat untuk penggunaan $r-H U$ $E P O$ sebagai agen terapeutik dan profilaktik.${ }^{17}$

Salah satu hasil penelitian yang paling awal dilaporkan oleh Halperin dkk (1991), pengobatan dimulai dengan $r-H U$ EPO dosis rendah 75-300 u/ $\mathrm{kgbb} /$ minggu pada usia bayi prematur berumur 2133 hari selama 4 minggu. Hasil menunjukkan peningkatan retikulosit tetapi tidak menyeluruh. Demikian juga penelitian-penelitian lain yang menggunakan dosis rendah tidak dapat memperbaiki eritropoesis secara bermakna ataupun mengurangi frekuensi transfusi darah merah pada anemia bayi prematur. Hal ini mungkin disebabkan dosis $r-H U$ $E P O$, suplementasi zat besi atau nutrien lain tidak memadai. ${ }^{1,16}$

Penelitian yang menggunakan dosis lebih tinggi dilaporkan Maier dkk (The European Multicentre), memberikan $750 \mathrm{u} / \mathrm{kgbb} /$ minggu pada bayi prematur usia 3 sampai 42 hari dan suplementasi preparat besi oral $2 \mathrm{mg} / \mathrm{kgbb} /$ hari selama 14 hari kemudian. Peningkatan hematokrit dan pengurangan jumlah volume transfusi darah dijumpai setelah 2 minggu pemberian $r$-HU EPO. ${ }^{19}$ Penelitian Shannon KM dkk (United State Multicentre), memberikan $500 \mathrm{u} / \mathrm{kgbb} /$ minggu ( 5 kali seminggu) selama 6 minggu, ditambah preparat besi oral 3-6 $\mathrm{mg} / \mathrm{kgbb} / \mathrm{hari}$ pada BBLSR menghasilkan rangsangan eritropoesis yang efektif, menurunkan kebutuhan transfusi darah dan relatif aman. ${ }^{20}$ Meyer MP dkk (South of Africa Centre), memberikan $600 \mathrm{u} / \mathrm{kgbb} /$ minggu dalam 6 minggu, ditambah preparat besi oral $3 \mathrm{mg} / \mathrm{kgbb} / \mathrm{hari}$ dan vitamin E $25 \mathrm{iu}$, memperlihatkan hasil pengurangan jumlah transfusi darah pada anemia bayi prematur. ${ }^{21}$ Beberapa penelitian selanjutnya melaporkan bahwa pemberian $r$-HU EPO dengan dosis yang lebih tinggi (>750 u/kgbb/minggu), lebih efektif meningkatkan retikulosit dibandingkan dosis yang lebih rendah dan tidak berhubungan dengan efek samping. ${ }^{4,22,23}$ Saat ini dosis pemakaian bervariasi antara 100-200 u/kgbb/kali (5 kali seminggu) dan 150-200 sampai $400 \mathrm{u} / \mathrm{kgbb} /$ kali (3 kali seminggu). ${ }^{2}$

Pemberian $r-H U E P O$ pada bayi prematur yang sangat kecil dan berisiko tinggi mempunyai efektifitas yang memadai. ${ }^{24}$ Ohls dkk, memberikan $r-H U E P O$ 
$200 \mathrm{u} / \mathrm{kgbb} /$ hari ditambah preparat besi $1 \mathrm{mg} / \mathrm{kgbb} /$ hari intravena selama 14 hari pada bayi premature dengan berat lahir <750 gram, menunjukkan hasil pengurangan jumlah transfusi darah dalam usia 3 bulan kehidupan dan tidak ada efek samping. ${ }^{25}$ Tetapi Maier RF dkk. berpendapat bahwa pemberian dosis $1500 \mathrm{u} /$ $\mathrm{kgbb} /$ minggu tidak dianjurkan pada bayi berat lahir amat sangat rendah $(<1000 \mathrm{~g}) .^{26}$

Penelitian lebih lanjut mengemukakan bahwa pemberian $r-H U E P O$ profilaktik pada minggu pertama kehidupan bayi prematur lebih efektif daripada pemberian lebih lambat. Denato dkk, menuliskan bahwa pemberian $r$-HU EPO pada usia lebih dini (72 jam) dengan dosis $1250 \mathrm{u} / \mathrm{kgbb} /$ minggu (5 kali seminggu) selama 6 minggu memperlihatkan peningkatan retikulosit dan hematokrit yang lebih tinggi dibandingkan pemberian pada usia lebih lambat (3 minggu), walaupun penurunan kebutuhan transfusi darah tidak berbeda bermakna pada kedua kelompok dalam usia 2 minggu kehidupan bayi prematur. ${ }^{27,28}$ Jumlah frekuensi pemberian 5 kali seminggu mempunyai efikasi lebih baik daripada 2 kali seminggu, walaupun penelitian lain melaporkan tidak dijumpai perbedaan efektifitas terhadap pemberian 1 kali atau 3 kali seminggu. ${ }^{29}$

Suplementasi besi pada pemberian $r-H U$ EPO pada anemia bayi prematur sangat penting untuk mendukung keberhasilan terapi. Penurunan kadar besi, feritin dan saturasi transferin serum setelah pemberian $r$-HU EPO menunjukkan cadangan besi jauh berkurang. Carnielli PV dkk, melaporkan terjadi peningkatan eritropoesis pada kelompok bayi prematur yang diberi $r$-HU EPO $1200 \mathrm{u} / \mathrm{kgbb} /$ minggu (3 kali seminggu) ditambah preparat besi parenteral $20 \mathrm{mg} /$ $\mathrm{kgbb} /$ minggu (1 kali seminggu) sejak usia 2 hari sampai 8 minggu. Pada minggu ke empat terlihat nilai retikulosit dan hematokrit lebih tinggi pada kelompok yang diberi suplemetasi besi dan nilai rata-rata feritin plasma jauh lebih rendah pada kelompok yang tidak mendapat suplementasi besi. . $^{23,30-34}$ Pemberian besi pada bayi prematur secara parenteral lebih dianjurkan daripada oral. ${ }^{16}$

Asupan protein terhadap eritropoesis selama pemberian $r$-HU EPO pada anemia bayi prematur mempunyai pengaruh yang besar. Pemberian protein di atas 3,1-3,5 g/kgbb/hari memperbaiki respons eritropoesis dan kegunaannya untuk pertumbuhan. ${ }^{33,34}$ Selain itu beberapa ahli menambahkan vitamin E 25 iu/hari, bermanfaat untuk mencegah terjadi defisiensi vitamin E yang menyebabkan hemolisis pada bayi prematur. Tetapi penelitian menunjukkan tidak ada pebedaan nilai hematologi antara kelompok terapi dengan kontrol. ${ }^{1}$

Preparat $r$-HU EPO diformulasikan sebagai cairan steril tidak berwarna dalam pelarut yang stabil dan diberikan secara intravena atau subkutan. ${ }^{10}$ Pemberian secara enteral tidak efektif karena tidak meningkatkan eritropoesis. ${ }^{35}$ Studi klinis memperlihatkan bahwa pemberian secara subkutan membutuhkan waktu lebih lama untuk meningkatkan kadar eritropoetin serum. Waktu paruh pemberian intravena antara 4-12 jam dan subkutan 8-12 jam. ${ }^{10,36}$ Dosis toksik pada tikus percobaan timbul pada pemberian $6000 \mathrm{u} / \mathrm{kgbb}$, dengan dosis letal $45000 \mathrm{u} / \mathrm{kgbb}$. Pada bayi prematur tidak diperbolehkan memberikan multidosis karena dijumpai pengaruh buruk dari benzil alkohol yang digunakan sebagai pelarut pada pemberian intravena. Saat ini telah dikembangkan 4 macam $r$-HU EPO yaitu alfa, beta, delta dan omega yang mempunyai perbedaan farmakokinetik dan farmakodinamik. Namun yang tersedia di pasaran adalah Epoetin alfa (Epogen, Eprex, Procrit) dan Epoetin beta (Neorecormon), dikemas dalam semprit, ampul dan vial dengan dosis $1000 \mathrm{u}$, 2000 u, 3000 u, 4000 u, 10.000 u dan 40.000 u..$^{9,10}$

Pada akhirnya harga merupakan pertimbangan lain penggunaan $r$-HU EPO pada anemia bayi prematur. Ohls dkk, menuliskan bahwa pemberian $r-H U E P O$ pda BBLSR selama 2 minggu usia bayi akan menurunkan kebutuhan transfusi darah sehingga mempunyai efektifitas biaya. ${ }^{37}$ Meyer MP dkk, melaporkan biaya 2 kelompok pengobatan antara $r$ $H U E P O$ dan kontrol hampir sama, tetapi risiko transmisi infeksi lebih rendah pada kelompok $r$-HU $E P O .^{38}$ Yeo CL dkk, melaporkan bahwa biaya BBLSR yang mendapat $r$-HUEPO $750 \mathrm{u} / \mathrm{kgbb} / \mathrm{minggu}$ secara subkutan (3 kali seminggu) selama 35 hari adalah $S \$$ 388 dibandingkan kontrol $\$ \$ 438 .{ }^{39}$ Harga $r$-HUEPO 2000 unit ampul adalah US 32,95 dan di Indonesia berkisar Rp 150.000- 250.000,-. Berbagai pendapat tersebut menunjukkan bahwa penggunaan $r$-HU EPO pada bayi prematur dengan anemia mempunyai keuntungan dan efektifitas hanya bila $r$-HUEPO dapat menurunkan jumlah transfusi darah. ${ }^{40,41}$

Demikian banyak penelitian telah dilakukan terhadap pemberian $r$-HU EPO pada anemia bayi prematur, tetapi sampai saat ini belum ada kesepakatan mengenai protokol pemberiannya, termasuk waktu, dosis, cara dan lama pemberian. 


\section{Efek samping}

Kejadian efek samping $r$-HU EPO pada bayi prematur lebih rendah dibandingkan dewasa. Beberapa kejadian yang dilaporkan adalah,

- Neutropenia: kemungkinan hal ini terjadi akibat persaingan pada sel induk (stem cell), karena eitrosit, granulosit dan trombosit berasal dari progenitor yang sama. Messer J dkk, tidak menjumpai kejadian neutropenia secara bermakna. ${ }^{1,18}$

- Infeksi: hal ini mungkin disebabkan oleh rendahnya cadangan besi dan pemberian suntikan subkutan. ${ }^{1}$

- Berat badan tidak bertambah: kemungkinan hal ini disebabkan kebutuhan protein dan kalori meningkat untuk proses eritropoesis. ${ }^{1}$

\section{Kesimpulan}

Pemberian $r$-HU EPO dapat meningkatkan eritropoesis pada bayi prematur sehingga bermanfaat mengurangi kebutuhan transfusi darah. Pemberian dalam dosis yang cukup, usia dini, penambahan suplementasi preparat besi dan protein mempunyai efektifitas yang lebih baik. Walaupun masih belum ada kesepakatan protokol pemberian $r-H U E P O$ pada anemia bayi prematur, namun dapat diharapkan dengan penelitian selanjutnya di masa depan.

\section{Daftar Pustaka}

1. Letsky EA. Anemia in the newborn. Dalam: Rennie JM, Roberton NR, penyunting. Textbook of neonatology. Edisi ke-3. Edinburg: Churchill Livingstone, 1999. h. 806-30.

2. Stoll BJ, Kliegman RM. Anemia in the newborn infant. Dalam: Behrman RE, Kliegman RM, Jensen HB, penyunting. Nelson textbook of pediatric. Edisi ke-16. Philadelphia: Saunders, 2000. h. 519-21.

3. Yu VYH, Monintja HE. Beberapa masalah perawatan intensif neonatus. Jakarta: Balai Penerbit FKUI, 1997. h. $105-28$.

4. Murray NA, Roberts IAG. Neonatal transfusion practice. Arch Dis Child Fetal Neonatal Ed 2004; 89:F101-7.

5. Hirano K, Marinobu T, Kim H, dkk. Blood transfusion increases radical promoting non-transferrin bound iron in preterm infants. Arch Dis Child Fetal Neonatal Ed 2001; 84:F188-93.

6. Canadian Paediatric Society. Red blood cell transfusions in newborn infant: reviced guidelines. Paeditr Child Health 2002; 7:553-8.

7. Lubis B. Eritropoetin pada sepsis pediatrik. Disampaikan pada Simposium Nasional Pediatri Gawat Darurat VI, Medan, 4 Oktober, 2003.

8. Strauss RG. Blood and blood component transfusion. Dalam: Behrman RE, Kliegman RM, Jensen HB, penyunting. Nelson textbook of pediatric. Edisi ke-16. Philadelphia: Saunders, 2000. h. 1499-503.

9. Ng T, Marx G, Littlewood T, Macdougall I. Recombinant erythropoietin in clinical practice. Postgrad Med J 2003; 79:367-76.

10. Amgen full prescribing information. Procrit epoetin alfa. 2000 June. Didapat dari: URL: http://www.procrit.com/ common/prescribing information/procrit/PDF/procrit booklet.pdf

11. Hoffbrand AV, Pettit JE. Kapita selekta haematologi. Jakarta: EGC, 1996. h. 1-27.

12. Ohls RK, Christensen RD. Development of the hematopoietic system. Dalam: Behrman RE, Kliegman RM, Jensen $\mathrm{HB}$, penyunting. Nelson textbook of pediatric. Edisi ke-16. Philadelphia: Saunders, 2000. h. 1456-60.

13. Israels GL. Mechanisms in hematology. Edisi ke-3. Canada: Core, 2002. h. 85-168.

14. Miller DR. Erythropoietin, hypoplastic anemias, and disorders of heme synthesis. Dalam: Miller DR, Bachner RL, Miller LP, penyunting. Blood disease of infancy and childhood. Edisi ke-7. St Louis: Mosby, 1995. h. 14082.

15. Schwartz E. Anemia of inadequat production. Dalam: Behrman RE, Kliegman RM, Jensen HB, penyunting. Nelson textbook of pediatric. Edisi ke-16. Philadelphia: Saunders, 2000. h. 1463-6.

16. Liesner RJ. Non immune neonatal anemias. Dalam: Lilleyman JS, Hann IM, Blanchette VS, penyunting. Pediatric hematology. Edisi ke-2. London: Churchill Livingstone, 2000. h. 185-99.

17. Shannon KM, Mentzer WC, Abels RI, dkk. Recombinan human erythropietin in the anemia of prematurity: results of a placebo-controlled pilot study. J Pediatr 1991; 118:949-55.

18. Meister B, Maurer H, Simma B, dkk. The effect of recombinant human erythropietin on circulating hematopoietic progenitor cells in anemic premature infants. Stem cells 1997; 15: 359-63.

19. Maier RF, Obladen M, Scigalla P, dkk. The effect of 
epoetin beta (recombinant human erythropoietin) on the need for transfusion in very low birth weight infants. N Engl J Med 1994; 330:1173-8.

20. Shannon KM, Keith JF, Mentzer WC, dkk. Recombinant human erythropoietin stimulates erythropoesis and reduce erythrocite transfusion in very low birth weigh preterm infants. Pediatrics 1995; 95:1-8.

21. Meyer MP, Meyer JH, Commerford A, dkk. Recombinant human erythropoietin in the treatment of anemia of prematurity: result of a doeble blind, placebo-controlled study. Pediatrics 1994; 93:918-23.

22. Avent M, Cory BJ, Galpin J, dkk. A comparison of high versus low dose recombinant human erythropoietin versus blood transfusion in the management of anaemia of prematurity in a developing country. J Trop Pediatr 2002; 48:227-33.

23. Reiter PD, rosenberg AA, Valuck RJ. Factors associated with successful epoetin alfa therapy in prematur infants. Ann Pharmacother 2000; 34:433-9.

24. Meyer MP, Sharma E, Carson M. Recombinant erythropietin and blood transfusion in selected preterm infants. Arch Dis Child Fetal Neonatal Ed 2003; 88:F41F5.

25. Ohls RK, Harcum J, Schibler KR, Christensen RD. The effect of erythropoietin on the transfusion requirements of preterm infants weighing 750 grams or less: a randomized, double blind, placebo-controlled study. J Pediatr 1997; 13:661-5.

26. Maier RF, Obladen M, Kattner E, dkk. High versus low dose erythropietin in extremely low birth weigh infants. The European Multicenter rhEPO study Group. J Pediatr 1998; 132: 866-70.

27. Donato H, Vain N, Rendo p, dkk. Effect of early versus late administration of human recombinant erythropoietin on transfusion requirements in premature infants: result of randomized, placebo-controlled, multicenter trial. Pediatrics 2000; 105:1066-72.

28. Ohls RK, Ehrenzkranz RA, Wright LL, dkk. Effect of early erythropoietin therapy on the transfusion requirements of preterm infants below 1250 grams birth weight: a multicentre, randomized, controlled trial. Pediatrics 2001; 108:934-42.

29. Brown MS, Keith JF. Comparison between two and five doses a week of recombinant human erythropoietin for anemia of prematurity: a randomized trial. Pediatrics 1999; 104:210-5.

30. Carnielli VP, Riol RD, Montini G. Iron suplementation enhances response to high doses of ecombinan erythropoietin in preterm infants. Arc Dis Child Fetal Neonatal Ed 1998; 79:F44-8.

31. Pollak A, Hayde M, Hayu M, dkk. Effect of intrvenous iron supplementation on erythropoiesis in erythropoietin treated premature infants. Pediatrics 2001; 107:78-85.

32. Maier RF, Obladen M, Messinger D, Wardrop CA. Factors related to transfusion in very low birth weight infants treated with erythropoietin. Arch Dis Child Fetal Neonatal Ed 1996; 74:F182-F6.

33. Brown MS, Shapiro H. Effect of protein intake on erythropoiesis during erythropoietin treatment of anemia of prematurity. Arch Dis Child 1996; 128:521-7.

34. Bechensteen AG, Haga P, Havorsen S, dkk. Erythropoietin, protein, and iron suplemen and the prevention of anaemia of prematurity. Arch Dis Child 1995; 69:19-23.

35. Juul SE. Enterally dosed recombinan human erythropoietin does not stimulate erythropoesis in neonates. J Pediatr 2003; 143:321-6.

36. Roche information. Neorecormon. 2004. Didapat dari: URL: http://www.emea.eu.int/human doe'/PDFs/EPAR/ Neorecormon/091096 ENG.pdf.

37. Ohls RK, Osborne KA, Christensen RD. Efficacy and cost analysis of treating very low birth weight infants with erythropoietin during their first two weeks of life: a randomized, placebo-controlled trial. J Pediatr 1995; 126:421-6.

38. Meyer MP, Haworth C, McNeill L. Is the use of recombinant human erythropoietin in anaemia of prematurity cost-effective ? S Afr Med J 1996; 86:251-3.

39. Yeo Cl, Choo S, Ho LY. Effect of recombinant erythropeietin on transfusion needs in preterm infants. J Paediatr Child Health 2001; 379:352-8.

40. Franz A, Pohlandt F. Red blood cell transfusion in very and extremely low birth weight infant under restrictive transfusion guidelines: is exogenous erythropoietin necessary? Arch Dis child Fetal Neonatal Ed 2001; 84:F96100.

41. Southgate WM. Anemia of prematurity. E Medicine 2002 May 3. Didapat dari: URL: http://www.emedicine. com/ped/topic 2629.htm. 